\title{
FULLER v. THE AMERICAN LEGAL REALISTS: AN INTERVENTION*
}

\author{
BY MYRES S. MeDOUGAL $\dagger$
}

Some few years ago a distinguished literary critic, confronted with the conversion of many of his friends to the Communist faith, tried to put himself in the place of the educated Greek or Roman "who discovered with amazement that his most intimate friends were turning" to that "strange new delusion," Christianity." To the many law students who have drawn inspiration from the hardy and sophisticated realism of some of Professor Lon Fuller's earlier writings must be recommended a similar imaginative, propaedeutic exercise if they are to hope to avoid bewilderment and maintain equanimity when confronted with this latest, and most ambitious, of that quondam skeptic's essays in Jurisprudence. ${ }^{2}$

The paradox and mystery of The Law in Quest of Itself is not confined to its title. ${ }^{3}$ Designed to rescue a sterile contemporary American

* A review of The Law In Quest of Itsecf. By Lon L. Fuller, Professor of Law, Harvard Law School. Chicago: The Foundation Press, Inc., 1940. Pp. vii, 147. $\subseteq$. Delivered as Rosenthal Lectures at Northwestern University in 1940.

$\dagger$ Professor of Law, Yale Law School.

1. Krutch, Was Europe A Success? (1933) 34.

2. Some indication of the comfort which Professor Fuller's lectures may lend to obscurantism is already of record. "It is most encouraging and gratifying to the foes of legal realism in its pseudo-sense to realize that the full prestige of Professor Fuller's scholarship and universally recognized competence in the domain of jurisprudence is being thrown into the battle on their side . . . He communicates mighty truths, yet he does so with the ease and deftness of expression of an essayist and with the penetration of a logician." Brown, Book Review (1940) 26 Iowa L. Rev. 173. Earlier in his review, criticising Fuller's vagueness, Professor Brown had written: "Unless some reasonably specific and intrinsically objective authoritarian content is postulated in the concept of natural law, it seems to be worthless as an evaluating instrument." Contrast the polite, but effective, deflation offered by Patterson, Book Review (1940) 26 IowA $\mathrm{L}$. REv. 166.

Hall, Book Review (1941) 19 N. C. L. Rev. 264 finds Professor Fuller's book "an important contribution to the creation of an enduring American philosophy of law" and "unmistakable evidence that we have definitely emerged from the doldrums in which so much of published American jurisprudence has stagnated in the recent past"; the author's criticism of the realists reveals him "at his best as one of the most acute legal philosophers in this country." Considerably less enthusiastic is Dillard, Bool Review (1941) 27 VA. L. REv. 568 who recalls that "natural law" was once described as the "pale moonshine of metaphysics."

3. Just who is questing for what and how? The Questing Beast, or Beast Glatisant, is well described by WHIte, The Sword IN the Stove (1939) 22: “. . . this Beast has the head of a serpent, ah, and the body of a libbard, the haunches of $a$ lion, and he is footed like a hart. Wherever this beast goes he makes a noise in his belly as it had been the noise of thirty couple of hounds questing." 
legal scholarship from the inhibiting influence of an "unseasonably positivistic" philosophy and, thereby, to encourage a "philosophic reexamination of basic premises" and a "more direct recourse to social and ethical desiderata," 4 this astonishing little book seeks to achieve such specified ends by redefining "law" as a diaphanous confusion of is and ought. No small task this for a definition, whatever the definition and whatever the faith! The choice which we all - judges, lawyers, teachers, and students (and legislators and administrators?) - have to make, the choice which determines how we will spend our working days, is, as Professor Fuller sees and poses it, between "natural law" and "positivism." For him, however, this is really no choice at all; and what he offers the rest of $11 \mathrm{~s}$ is equally a Hobson's choice: attacking and rejecting "positivism" as impossible nonsense, he goes off the deep end for "natural law." It becomes important, therefore, to try to determine what he means by these two highly ambiguous symbols and where his meaning, if ascertainable, will lead us. His general theory of "the meaning of meaning," of the relation between verbal and non-verbal events, may also become an inescapable subject of inquiry.

The "natural law" which Professor Fuller proposes as a cure for our academic and social ills is not startlingly new." It is - as he expounds it with a truly "variable content" - a philosophical "attitude" which views "law" as "reason applied to human relations" and "denies the possibility of a rigid separation of the $i$ and the ought." Bowing to the "obscurity of nature" which does not "present us with the is and the ought in neatly separated parcels," it "tolerates a confusion of them in legal discussion" and does not dissipate energies "in a fruitless attempt to separate the inseparable." "In the field of purposive human activity . . value and being are not two different things, but two aspects of an integral reality." Though there are no absolute and inalienable rights, natural law if "temporarily eclipsed" by "bad" state law has a "goodness" which gives it "a kind of reality" never "wholly nullified." Its chief value, so Professor Fuller insists, is not in the content of any of its many systems, but in a "way of thinking." Its illusion that there is "no limit to what human reason can accomplish" "liberates the energies of men's minds and allows them to accomplish as much as they can."

Foreclosing this heaven of human aspiration is the clevil of "posi-

4. The two latter quotations are taken from Fuller, Williston on Contracts (1939) 18 N. C. L. REv. 1, a review which the author incorporates by reference into his book.

5. Both the Greeks and the Romans had something like it. Barker, Translator's Introduction in GIERKe, Natural LAW AND THE Theory of SOCTETY (1934) xxiv; Jones, Historical Introduction to the Theory of Law (1940) 98.

6. These and the following quotations are taken from all portions of the book. Page citations are omitted since similar language can be found at recturrent intervals throughout the book. The significance of the weasel words "sharp" and "rigid" appearing in some of the quotations is not developed by the author. 
tivism." Professor Fuller's conception of this is, in contrast, as novel as it is uninviting. He lumps Hobbes, Austin, Kelsen, Somlo and a host of others in a single wondrous category with the "American legal realists." The tie which is supposed to bind all these people together is an obsession with "the law's" futile quest for "itself" - "a quest for some exclusive hegemony of its own, for some Ultima Thule where its existence can be free from the complications of ethics and philosophy." Each and all have been seeking "some test" which would enable them "to say when a rule should be given that particular sanction due rules of law"; they insist on "drawing a sharp distinction between the law that is and the law that ought to be." But Hobbes, Austin, Kelsen and all the others who seek a test in some kind of a "sovereign," varying from a "datum of nature" to a "methodological premise," invariably end up with a tautology instead of a test. Having eliminated "the normative order," they cannot explain how the sovereign gets to be a sovereign, ${ }^{7}$ why there are gaps in the law, how judges can legislate, and so on. Their intellectual fruit is sterile debate about a theological trinity of Law, State, and Sovereign with little reference to the ends which these entities are intended to serve.

Straight from this same tradition, so it is alleged, stem the American legal realists. Hard after the "pure fact of law," they move out of "the field of concept and interpretation" and define law as "the behavior patterns of judges." Their criterion is not "what judges say" but "what judges do." But why then-asks Professor Fuller, seeking a devastating reductio ad absurdum - stop with judges? Why not include the behavior patterns of commissioners, sheriffs, sanitary inspectors, and all other state officials? How indeed, without a "normative order," exclude the behavior of laymen?8 Must not in fact a realist's "law" include the behavior of

7. The discussion of this pseudo-dilemma is an excellent example of the lack of consciousness of levels of abstraction-of the slippery and misleading abuse of wordswhich pervades the book. It is urged, quoting Kunz with apparent approval, that the positivists cannot eliminate the "normative order" because "it is the lorw alone which makes a man a judge," and again in similar vein that the "sovereign" cannot "establish a boundary about the field of law" because the "sovereign" itself "can only be defined in legal terms." Because certain writers insist that for the study of certain problems they are more interested in what judges do than in what they say they do, must they be forced to reject the whole institution of government? Does the symbol "law" have the same referent, is it used at the same level of abstraction, in both horns of this alleged dilemma? Surely it is possible to criticize some norms without rejecting all others.

Elsewhere in the book Cook is forced by the author to assume "a unified legal order" because he asserts "that where equity will restrain the enforcement of a legal right, the legal right is not actually 'valid." Why must Cook be made to extrapolate so broadly? All he need assume is that, as between courts of law and courts of equity, courts of equity have the last word. Such phrases as "a unified legal order" and "the pure fact of law" suggest an absolutism and a peculiar kind of absolutism foreign to all Cools has fought for in a long and influential career.

8. Note again the misleading transition from one level of abstraction to another. 
everyone? What, furthermore, is "behavior," as distinguished from "meanings and intentions"? Movements of the arms or of the jaws? Or is it movements at all? Who ever saw a "behavior pattern" of a judge or knows what one would look like?(!!) More inhibiting, however, than the realists' emphasis upon an impossible $i s$, is their alleged general skepticism about the ought, a skepticism about "the ethical foundations of legal rules" ("a background against which 'the law as it is' appears as an accidental configuration without lasting importance!"). The greatest danger of legal realism is, not in its definition of "law," but in its "positivistic spirit": in a "denial of the force which ideas have without reference to their human sponsorship" and in a conviction that "nothing that transcends personal predilection can be said about the laze that ought to be." Seeking "the basic fact of law beyond which all research is useless," such a positivistic spirit ignores the "moral facts" which "lie not in behavior patterns, but in attitudes and conceptions of rightness, in . . obscure taboos and hidden reciprocities . .." In a period "when major readjustments in our economic and social order" are necessary, it offers a notion of democracy no "closer to the inner essence of things than the will of any particular individual." Viewed from this perspective, the realists, Professor Fuller sums up, despite some effective debunking of a "sort of verbal trifling," have achieved little more than a continuation and reinforcement of the restraints which have inhibited "legal thinking in this country now for nearly a century."

Implicit in the above summary - let us hope that the author may think it a caricature ${ }^{9}$ - are, of course, many criticisms of the argument. It is easy indeed to agree with Professor Fuller that, compared with "the law's quest for itself," the well-known philosopher in a dark room chasing a black cat that isn't there is engaged in fruitful, creative work. ${ }^{10}$ Likewise, few critics could have anything but applause for his ultimate objective of revitalizing our contemporary American legal scholarship or for his avowed zeal for social reform. But when we come to the

9. For insurance against some idiosyncratic myopia, I submitted the book to two of my best students and one of my colleagues for independent judgments. Their analyses, though even less sympathetic, were substantially similar to mine. Caricature or not, one fact is certain: four people at least; not unaccustomed to reading books, see the same ambiguities and are puzzled by the same futile shuffing and reshuffling of equivalent ambiguities without any discernible progress toward a usable system for social observation and analysis.

10. Some justification for the author's concern may perhaps be found in a recent query by one of his reviewers: "If Professor Fuller wishes to include both the law that is and the law that ought to be under the term 'law,' the same problem remains: What is the criterion by which he will distinguish that 'law' from 'non-law'?" Cairns, Book Review (1940) 54 HaRv. L. Rev. 157. On with the Quest and damned be he who first shall cry "enough!" Later in his review, it must in fairness be said, Mr. Cairns asks more simply: "What is an intelligible field of legal study?" It may be that he too is merely asking Professor Fuller to specify what he is talking about. 
means by which the author proposes to achieve his admirable purposes, agreement must perforce end. More precisely, agreement, however hopeful and sympathetic, becomes impossible because communication fails. Whatever meaning the author may have is quickly and irretrievably lost in the impregnable multiguity of his specific key symbols and in his almost omnipresent general confusion about the relation between "facts" (non-verbal events) and "theories" (verbal events)." Never does he give any indication of how natural law or ethical ideas can guide us to specific social goals or even how such ideas can be used to implement goals otherwise specified. An indictment so sweeping may, perhaps, require some further particularization.

Most important of the many symbols which go around and around in all this muddled discourse is the word "law." For just what referent is Professor Fuller using this symbol? What is he trying to define and how ${ }^{12}$ Obviously, he is not making a naturalistic, descriptive study of the variety of ways in which other people now use the word; he is setting up a system, stating his own preference as to how the word should be used. It is to include both is and ought. But what "is"13 and what "ought"? 14 All of both? The whole "big, blooming, buzzing confusion"

11. In the idiom which Mrr. Stuart Chase has made popular [Tre TrRa:tiy of Words (1938)] Professor Fuller could be said to be guilty of a confused "semantics." See Morris, Foundations of the Theory of Signs in INTERNatrosal Excrclopedu of UNIFIEd ScIENCE, Pamphlet 2, Vol. 1 (1938). This is all the more distressing in an author who made his philosophical debut with an acute study of how legal concepts are formed and used. Fuller, Legal Fictions (1931) 25 ILL. L. Rev. 363, 513, 877. Symptoms of the present trouble can, however, be found in Fuller, American Legal Rcalism (1934) 82 U. of PA. L. Rev. 429. There the author criticises Llewellyn for suggesting that judges in applying old concepts to new cases are continually expanding and changing the meaning of such concepts and finds this realist "error" in a "belief that the individual in his own private thinking does not employ universals and abstractions and that these things are only convenient devices for the communication of ideas."

12. This is no Quest. I do not ask for an absolute. Professor Fuller can draw the line between "legal" and "non-legal" wheresoever he pleases. What I do ask is how he is using the word in this book: Where he is drawing the line in a specified context for a specified purpose.

13. The possibilities are infinite. "What 'is' this, that or the other? 'Is' this an apple, or 'is' it a projection in space and time of an ideal, extra-spatial, extra-temporal, non-rottable apple, 'existing' in the changeless and eternal realm of 'ideas' as the ethereal appleness of all the little apples God ever made." Beir, Tre Searcr gos Truta (1934) 97.

14. Possibilities here are equally extensive. From any specific case, as Oliphant has demonstrated in his $A$ Return to Stare Decisis (1928) 14 A. B. A. J. 71, 159, can be extrapolated an infinite series of normative (or descriptive) statements of ever-increasing generality. Conversely, normative statements of high generality can be made, by giving the words proper indices, to support any specific end. Beginning at top or bottom, a legal philosopher can find any amount of ought at any level of abstraction.

It is this accordion-like flexibility of the universal ought which malses possible the precious virtuosity by which Professor Edward Levi translates Arnold into Adler, and 
about us? Presumably not; he laughs at the realists for including "behavior," judicial and otherwise, within the ambit of the word and he makes a repeated distinction between the "moving world of fact" and "the moving world of law." Though the word floats through his book with a maddening instability of reference, its most constant meaning seems to be "rules," verbal statements. ${ }^{15}$ But what kind of rules? Stated by whom? Stated by scientists, teachers, administrators, judges, constitution-makers or priests, or by all of these? When there is conflict between statements, which embodies Fuller's "law"? A chaos of words is just as confusing and just as unmanageable as a chaos of behavior. Whence cometh our philosopher's stone? Is Professor Fuller suggesting only, what is demonstrated countless times daily, that judges, administrators, and the rest of us, owe no unquestioning deference to all or any of the normative statements to be found in books? Is he attempting to do nothing more substantial than restate the generally accepted notion that it is impossible to pin neat labels of "legal," "social," "economic," "ethical" etc. on all the norms, prescriptions of conduct, and preferential statements to be found in a modern culture? Or is he merely reemphasizing the equally common notion that it is often difficult to distinguish between naturalistic statements and preferential statements? Surely not. Both the complexity and the length of his discourse would indicate that he is trying desperately to do something more. But what?

From the empyreal heights, sketched in vague outline above, no meaningful answer comes or can come. Just what are these "moral facts," these "meanings" and "intentions" - "attitudes," "conceptions of rightness," "obscure taboos," and "hidden reciprocities" - which are to be contrasted with "behavior patterns"? By just what modus operandi are they to be studied? Exactly how is the ethical philosopher to make the salto immortale from the "predilections of individuals" to the "inner essence of things"? Not a single hint - not one glimpse of the sacred text - does the author give us. How true it is that "nature" does not "present us with the is and the ought in neatly separated parcels"! Nature doesn't present us with anything, not even "natural law," in neatly separated parcels: we have to slice nature as we do cheese, in the ways that suit our convenience and our specific practical purposes. ${ }^{10}$ For naturalistic study of governmental institutions and their effects on people, the realists now find convenient a "behavior patterns" slice; for spiritual exhortation, Professor Fuller in turn prefers "integral realities." The one

vice versa. Levi, The Natural Law, Precedent, and Thurman Arnold (1938) 24 VA. L. Rev. 587.

15. See, for examples, pp. $10,33,35,38,64,76,111$. One may wonder, in a not cntirely irrelevant aside, how meaningful rules can exclude behavior or fail to distinguish between actual behavior and desired behavior.

16. Burke, Pernanence and Change (1935) 136. 
is just as easy, and just as difficult, to "see" as the other. The taking of distinctions, as Professor Fuller himself says," implies no "permanent bisection of the subject matter involved"; "unities" (or "dichotomies" or "pluralities") whether of "fact" or of "law" or of "ethics" or of "ethics-law" are personal creations and creations for purposes. 18 Why must Professor Fuller so insistently oppose "datum of nature" and "methodological premises" or "facts" and "concepts and interpretations"? It is a false and hopelessly confusing opposition: "concepts" and "interpretations" and "methodological premises" are simply our man-made, custom-built tools for slicing "facts" or the data of "nature."

It must, of course, be agreed that within the confines of a philosophy which regards words as mere convenient tools, Professor Fuller is free, if he so desires, to attempt to slice the "big blooming buzzing" world about us (what he calls a "moving and fluid reality" in which everything is merged into everything else) with a single, blunder-buss, verbal isought. The relevant question is only as to the effectiveness of such a crude technique for achieving his specified ends. In his "moving and fluid reality" he must be able to observe people ordering each other about and doing things for and to each other, acting through "institutions" some labelled "governmental" and some not - a veritable melee of judges, administrators, legislators and, yes, sanitary commissioners and laymen. Attendant upon all this activity he must also be able to observe a plethora of verbalization at all levels of abstraction : statements purporting to describe this behavior, its uniformities and its irregularities, and its conditions and consequences; statements by the actors of what they think they are doing and why; statements by teachers, philosophers, and priests as to what the actors ought to be doing; and so on. ${ }^{10}$ For coping with this maelstrom of "integral reality," social scientists have in the past found it reasonably helpful, as a basic initial discrimination, to distinguish between existing conditions and desired events, naturalistic statements and preferential statements, and "being" and "value"; and it has long been assumed that, if they are to achicve still more knowledge about and control over all this behavior and verbalization, their efforts must continue to be directed for some time to come toward a sharpening

17. At p. 58. This is one of the few reversions to an earlier insight. See note 18 , infra.

18. Fuller, Legal Fictions (1931) 25 ILL. L. REv. 363, 372, 905. Compare Ap.12ss, Mont-Satnt-Mitcher aNd Chartres (1933 ed.) 348: "Unity to him (the nominalist) was a pure concept, and anyone who thougit it was real would believe that a triangle was alive and could walk on its legs."

19. For complex, unnecessarily complex, elaboration, see Llewellyn, The Nornotize, The Legal, and The Law-Jobs: The Problem of Juristic Method (1940) 49 Yale L. J. 1335. An answer to Professor Fuller, though not explicitly addressed to him, appears at 1370 under the heading of "Philosophical Caveat and Excursus." 
and clarification and not an obfuscation of their symbolic and analytical tools. ${ }^{20}$

The American legal realism which Professor Fuller attacks is, to particularize still further his general misdirection of energy, a bogus American legal realism. John Austin, Kelsen, and others, from abroad and at home, may have done their bit to "separate the inseparable"; but most of the men whose names appear upon Professor Llewellyn's famous list of American legal realists ${ }^{22}$ are innocent men. So also are most of their followers. They do not deny that the law-in-fact (rules and behavior) ${ }^{23}$ embodies somebody's ethical notions (how absurd it would be to deny it!); on the contrary, they are the people who have been most insistent that it has too often embodied an ossified ethics, inherited from previous centuries and opposed to the basic human needs of our time. More clearly than any of their critics, the realists have appreciated that legal rules are but the normative declarations of particular individuals, conditioned by their own peculiar cultural milieu, and not truths revealed from on high. Most of their writing has, in fact, been for the avowed purpose of freeing people from the emotional compulsion of antiquated legal doctrine and so enabling them better to pursue their hearts' desires. ${ }^{24}$ Not bothering to explain how judges can legislate, it is they who have insisted that judges do and must legislate, that is, make a policy decision, in every case. The major tenet of the "functional approach," which they have so vigorously espoused, is that law is instrumental only, a means to an end, and is to be appraised

20. Compare Fuller, supra note 18 , at 886 .

21. We have all been brought up to drub poor old Austin and his "sovereign." But in his defense, against the kind of attack to which Professor Fuller subjects him, it must be said that any key symbol, any top abstraction, in a system of social analysis must leave many particulars of the system unexpressed. The important focus of attention for a critic should be on the subsequent specification of these particulars.

22. Llewellyn, Some Realism About Realism (1931) 44 Harv. L. Rev. 1222, 1226. Without undertaking to defend everything which has been written in the name of "legal realism," I am willing to assume, as Professor Fuller does, that these men and their followers form an identifiable group.

23. For more systematic exposition, I would invoke Malinowski's concept of an "institution," which seeks to place an adequate emphasis on both rules and behavior. See Malinowski, Culture (1937) 4 Excyc. Soc. Scr. 621; The Group and the Individual in Functional Analysis (1939) 44 AM. J. Soc. 938; The ScIentific Basis of Applied Anthropology (1938); Hamilton, Institution (1937) 8 Encyc. Soc. Scr. 84. What "institutions" I would label "legal" would depend entirely upon convenience for the problem at hand. The focus of my concern would be, whatever the label, upon enlightened and effective exercise of collective initiative and powers. Some indication of the scope of "convenience" for three practical problems can be found in Book Review (1941) 54 HARv. L. Rev. 526.

24. Sampling a large number of Articles, I find none which does not in one form or another state this purpose. It is explicit even in Articles which Professor Fuller picks out for especial opprobrium: Cook, The Logical and Legal Bases of the Conflict of Lazes 
only in the light of the ends it achieves. ${ }^{25}$ Any divorce they may at times have urged between is and ought has been underscored always as temporary, solely for the purpose of preventing their preferences from obscuring a clear understanding of the ways and means for securing such preferences. ${ }^{26}$ Directly contrary to Professor Fuller's charges, they have sought to distinguish between the is and the ought, not for the purpose of ignoring or dismissing the ought, but for the purpose of making a future is into an ought for its time. Without wasting their energies in trying to find out what "law" really $i s^{2 \pi}$ or in seeking some inevitably circular and infinitely regressive logical justification for their preferences in the transcendental nebulosity of the rational sciences of politics and ethics, ${ }^{28}$ they have been hard at work for the achievement of certain

(1924) 33 Y ALE L. J. 457; Cook, Williston on Contracts: Revised Edition (1939) 33 ILI. L. REv. 497; Llewellyn, A Realistic Jurisprudence-The Next Sicp (1930) 30 CoL. L REv. 431. For one of the most persuasive statements of the realist position see Yntema, Legal Science and Reform (1934) 34 CoL. L. Rev. 207. Frank writes in Mr. Justice Holmes and Non-Euclidean Legal Thinking (1932) 17 Cos:. L. Q. 56S, 585:

"All those known as legal realists or legal sceptics are eager-perhaps altogether tou eager-to improve the judicial system, to make it more efficient, more responsive to social needs, more 'just,' if you like that word. They are unflagging idealists disgruntled with the way the courts do their work; they are tireless critics of the existing ways." Compare the early article by Corbin, The Law and the Judges (1913) 3 YALE REv. 234.

25. Note the excellent answers to Professor Fuller's arguments, as if by anticipation, in Felix Cohen, The Problem of a Functional Jurisprudence (1937) 1 Mod. L. REv. 5.

26. Llewellyn, stipra note 22 , at 1236 , states this as clearly, strangely enough, as words can state it.

27. In the present state of our knowledge the search for an absolute-or its ghost: a "proper definition"- seems a bit premature. By way of footnotes $(50 \mathrm{n} .8,52 \mathrm{n}$. 11) Professor Fuller concedes that the "question of 'the unity of the legal order' has not preoccupied the later American realists" and "that only a few of the 'realists' listed by Llewellyn have concerned themselves with the problem of defining law" or "have talien any definite stand on the issue of natural law zersus positivism." He also reaffirms an earlier generous concession (Fuller, American Legal Realism (1934) \&2 U. of PA. L. REv. 429,434 , cited here at $130 \mathrm{n}$. 14), that one "of the chief services of the realist school has been to enlarge the field of the legally relevant and to invest 'extra-legal' considerations with a species of respectability." Should not this suggest to him that a "definition" of law is much less important than he apparently assumes-that judges, lawyers, law teachers, and law students do not really determine by a "definition" how they will spend their working days. His present apology for continued attack on the realists "that the prevailing philosophy of our law schools has (not) as yet caught up with this broader conception of legal method" scarcely sustains his argument!

28. Some of Professor Fuller's appeals for a high-order ought come perilously close to demanding of legal scholars the kind of "thobbing" which Ifr. Aortimer Adler has lately made so infamous. See, inter alia, God and the Professors, and the replies thereto in The Chicago Daily Maroon, Nov. 14, 1940. It is interesting to note that Mrr. Adler, too, finds the root of all our ills in "positivism" and our only hope of salvation in an unidentified "natural law" (along with, of course, metaphysics, theology, and the usual trimmings). 
humanitarian and democratic ideals of intermediate or relatively lowlevel abstraction, which most of us share today: civil liberties, social security, more goods to more people, healthful housing, conservation and full utilization of resources, collective bargaining, farm security, socialized medicine, protection of consumers, protection of investors, cheaper and better administration of justice, and so on. ${ }^{20}$

The basic problem to which we must all - author-critic, ${ }^{30}$ realists, fundamentalists, and reviewer - eventually get back is this: what is the most effective strategy, where can we best concentrate our energies, for securing certain generally accepted social ends? Stupid as it is to forget what we are trying to do, ${ }^{31}$ it is equally stupid to ignore how to do it.

For the realists, personal "values" ("oughts," "preferences," "ideals," "goals," "desired events") are the product of an as yet inadequately explored interaction of inborn nature and culture. Implementation of such values, they have found, can come only from science and effective social controls. The "logical derivation" of values from assumed postulates of theology, metaphysics, and ethics, very specialized parts of our culture, they regard not as the highest form of intellectual achievement but as a waste of time and energy. Such specious rationalism interests them only as any "case" material interests a psychiatrist or an anthropologist or when it is used to oppose, or detract attention from, specific values in which they are interested.

The conservative or even reactionary social implications of a rarified "ethics," wholly apart from its sad misdirection of human energies, is indeed a theme which might bear development. Despite all his protestations about our living "in a period when major readjustments in our economic and social order" have become necessary, some of Professor Fuller's own pronouncements are a little suspect: he attacks "bureaucracy" and demands a government preeminently by judges; the chief social reform he urges is an extension by the force of ideas of an "autonomous order" "not dependent upon any governmental structure"; he prefers "judicial" to "legislative" reform; the faith he wants is the one "which promises the most sustenance for our spiritual needs"; "majority rule" not based on "right" is a "negative" conception of democracy; democracy fell in Germany and France, apparently, because the people did not have a "faith in ideas." Whatever the inferences to be drawn from these attitudes, one fact stands out: Professor Fuller nowhere indicates how his "natural law" could be made into effective propaganda for social reform or offers us anything more specific than a kind of religious assertion of the value of any ethics which eschews positivism. This is not surprising; it is well within the tradition of ethical philosophers. Recall here the expert testimony of Felix Cohen: "It would not be unfair to say that no avowed ethical philosopher in the last hundred years has made a single fundamental criticism of the established institutions of modern society." Cohen, Ethical Systems and Legal Ideals (1933) x. Compare Nelles, Book Review (1933) 33 Cor. L. Rev. 763.

29. Some of the most ardent reformers in public life today (e.g., Frank, Arnold, and Douglas) won their first intellectual spurs by contributions to the realist movement. Dozens of others work less prominently, but no less effectively, with law review articles and judicial opinions.

30. Presumably even Professor Fuller would have the legal scholar eventually dismount his high-order ought and attack some relatively specific end. What else can he mean by his insistence that legal philosophy "give a profitable and satisfying direction to the application of human energies in the law?" One charge he makes against "positivism" is, furthermore, that it is divorced from "a definite or practical goal."

31. Nietzsche's "trenchant dictum" which Professor Fuller several times quotes. 
The time has long passed, if ever it was, for preaching pseudo-inspirational sermons in a highly rarified, impersonalized, and dehumanized "ethics," or for insisting only, with bated breath, that courts consciously, overtly, and deliberately take "policy" into account in rendering their decisions. Doctrinal purification, whatever the doctrine and whatever the purification, as the realists have so long been urging and as the restatement folly of the past two decades so well demonstrates, is not enough for achieving the reforms which most of us today desire and demand. ${ }^{32}$ The time has come, if impending social changes are to be effected with a minimum of violence, not only for an imaginative utilization and improvement of our existing legal resources but also for the conscious and purposive creation of new social controls. ${ }^{33}$ It is a commonplace today that the judicial institution, indispensable though it may be for the preservation of many of our old and continuing values, does not exhaust the possibilities of collective action; before too many of our modern, complex problems, requiring as they do for their solution a continuous and informed exercise of highly specialized skills, our traditional courts are, in the first instance at least, utterly helpless. ${ }^{3 s}$ When Professor Fuller attacks "bureaucracy," finding it, by a strange misconception, based on moral attitudes no "less abstract than mere respect for the will of the state," and demands "a government preeminently by judges," or when he bases his chief hope for social reform on some mystical "autonomous order" to be created by the force of ideas and "not dependent upon any governmental structure," he is attacking our most significant, emergent institutions and but vainly trying to bury his head in sands which have long since been blown to the Valhalla of all ana-

32. A theme on which Thurman Arnold has written two books, one a best seller, and numerous articles, should require no further elaboration here. But documentation of the argument as to one problem, the conservation and utilization of water resources, can be found in McDougal \& Runyon, Book Review (1940) 49 YaLE L. J. 1502.

One of Professor Fuller's most fervent pleas, in fact his climactic appeal for social reform, is for a resuscitated "autonomous order," a "spontaneous ordering of human relations" by the force of ideas "not dependent upon any governmental structure." It would be interesting to see just how he would handle with his "autonomous order" and spontaneous ideas such simple drainage basin problems as flood control, soil erosion, pollution, city supply, and power development. The American people are just now beginning to awaken to the fact that they have had for, several decades entirely too much "autonomous order" in the handling of such problems.

33. For a brief and clear indication of some of the possibilities, see Rostow, Book: Review (1941) \& U. of Chi. L. Rev. 169. Compare Nat. Resources Coans., The StrucTURE OF THE Axrertcan Econonry, Part I (1939) and Part II (1940); Gray, The Passing of the Public Utility Concept (1940) 16 J. LaNd \& P.U. ECosr. 8; Frankfunter, The Public and Its Governarent (1930); Lilienthal \& Marquis, The Conduct of Business Enterprises by the Federal Gozcrnment (1941) 54 HaRv. L. Rev. 545.

34. Landis, The Adninistrative Process (1938) 6-47; Acheson, Summary of Report of Attorney General's Committee Urging Changes in Procedure of Federal Agencies, N. Y. Times, Jan. 25, 1941, p. 9, col. 2. 
chronistic and wistful, wishful thinking. Few competent observers today doubt the relative permanence of our new administrative boards and governmental corporations - whether national, regional, state, or local - as effective instruments for the informed exercise of an ever increasingly indispensable collective initiative. It is indeed becoming ever more obvious that what our truly revolutionary times demand, if the democratic values which most of us cherish are to be secured and preserved, is the deliberate invention of more of these new agencies - of more new administrative boards, arbitration boards, government corporations, government-private corporations, government-regulated corporations, and so on - of institutions, "legal" or "non-legal" or what you will, adequately staffed and with staffs trained in the proper skills for exercising all of the vast powers which our democratic form of government makes available for us.

The task which such a prospect poses for legal scholarship is, beyond doubt, as fearful as it is formidable. Professor Fuller's problem of a more enlightened, vigorous, and fruitful scholarship is, by any persuasive chart of probable future trends, an important problem. But a belief that the requisite academic skills, enlightenment, and interest can be nurtured in a new definition of law and especially in a definition which, gulping the whole world of verbalization with a single swallow, deliberately confuses ends and means ${ }^{85}$ must surpass even a "natural law's" limitless reason. A Quest more fantastic could scarcely be imagined. What hope there is for an effective legal scholarship in this country would still seem to lie not alone in a moratorium on all Quests, but also in a continuing earthy struggle for what the realists have been demanding for at least two decades: a system of social analysis which places a balanced emphasis on ends and means and, equally important, bigger and better research and educational institutions for exploiting the possibilities of such a system. The much publicized "functional approach," calling as it does for a clear and deliberate specification of relatively concrete social ends ${ }^{30}$

35. The unnatural quarrel between is and onght which Professor Fuller creates in order to achieve this ultimate confusion has been described by Professor Harold D. Lasswell, with customary insight, as a skill struggle between individuals: "Those who excel in naturalistic analysis may proclaim the virtues of 'objectivity' and refer with condescension to those who imagine, the world is interested in the lengthy elaboration of their system of private preferences. The specialists on normative styles of speech may refer disparagingly to the absence of ethical fervor of the ostriches who bury their heads in the sand of science while the war of values is upon us." Lasswetr, Pourtics: Wuo Gets What, When, How (1936) 151. The reader who is familiar with Professor Lasswell's books will recognize that I have filched several phrases and ideas from his rich stores.

36. Far from "eliminating the normative" or "minimizing the force of ideas," the realists seek to use all of the skills and insights known to public relations experts, propagandists, and psychiatrists and include "normative statements" and "ideas" in the naturalistic phenomena about which they hope to gain more information. For them the exact 
and for an equally clear and deliberate survey and marshalling of all of the available controls and techniques for securing these ends, ${ }^{37}$ offers at least the beginnings of a fruitful system for social observation and analysis. The great tragedy is, of course, that the research and educational institutions - institutions with adequate resources, organization, and staff - for the effective exploitation of such an approach have never been forthcoming. It is no cause for wonder that the fruits of "realistic" research have been, as Professor Fuller insists, pitifully small compared to the noise. ${ }^{38}$ How many, if any, of the law schools in this country today are adequately organized with ample resources for effective research or even for the second-hand use of effective research by governmental agencies ? ${ }^{39}$ How many law teachers have the leisure, resources, and expert assistance to do much more than string cases on dubious oughts? Despite all the intoxicating mystery of an infinitely variable and mostly incomprehensible "natural law," it is still not entirely improbable that the more effective way to encourage a creative legal scholarship in this country today and with it "a more direct recourse to social and ethical desiderata" is, not by firing feather barrages at one's only allies in purpose, or by reconciling Science and God and calling it Law, but by seeking the organization and endowment of better law schools: that is, of law schools adequately staffed with all of the skills of modern social science and with resources ample for the exercise of these skills in both investigation and teaching. ${ }^{40}$ In such schools it might eventually come to pass that the

interrelation of material and ideological factors in social change is another problem to be investigated, not by nebulous speculation, but by careful, scientific observation and analysis.

37. Here is where the realists, for the sake of accuracy in their study of the conditions and consequences of various controls, attempt their temporary divorce of the is and ought. Not even President Hutchins bans such study from the legal scholar's domain. Hutchins, Legal Education (1937) 4 U. of CEI. L. REv. 357.

Pending acquisition of more exact knowledge about such conditions and consequences, Professor Fuller rightly demands the exercise of common sense. Praising Proiessor David Cavers' Law and Contemporary Problems, he concedes the value both of statistics and of a "homely kind of information." The "tremendous importance of such facts for the law" was brought home to Professor Fuller in preparing The Special Nature of the Wage-Earner's Life Insurance Problem (1935) 2 Law \& Costeasp. Pros. 10. Note at page 28 of this article, when the author is working with a practical problem, a preference for "paternalism" as opposed to "legalism."

38. The record of the realists, considering their institutional handicaps, is more impressive than is sometimes imagined. Llewellyn, On Reading and Using the Ncrecr Jurisprudence (1940) 40 CoL L. Rev. 581, 606; HaLL, Readivgs on Jurisprudes:ce (1938) 1168. To the documentation offered by these two writers could be added also much recent effective research, conducted under the direction or inspiration of the realists, by governmental agencies. An appropriate $t n$ quoque, is, of course: what have the "cthical" philosophers ever produced? See note 28 supra.

39. The familiar contrast with medical schools is as apt as when first made.

40. See Riesman, Law and Social Science (1941) 50 YALE L. J. 636, 610. 
principal policy makers and executors of our society and their teachers could be trained as such, and not as priests in outworn and meaningless faiths whether of "law" or of "ethics," or of some necromantic amalgam of "ethics-law." 41

41. If I have mistaken for a serious essay, what was intended as poetry, I still prefer two verses from ThoNAS HARDY, NEw YeAR's DAY 1906:

Then he: "My labours-logicless-

You may explain; not I:

Sense-sealed I have wrought, without a guess

That I evolved a Consciousness

To ask for reasons why.

"Strange that ephemeral creatures who

By my own ordering are,

Should see the shortness of my view,

Use ethic tests I never knew,

Or made provision for!"

But evidence continues to accumulate that I am justified in taking the essay seriously. Hot off the press is Brecht, The Myth of Is and Ought (1941) 54 HAnv. L. Rev. 811 which concludes that "the allegedly eternal and unbridgeable gulf between is and onght is but a myth." Gladly accepting "the proposition that purely logical conclusions must not pass from statements of is to statements of ought," this latest contributor to our epistemological confusion insists "that between the two realms there are manifest factual links which have factual support sufficient to render the separation more or less irrelevant." Despite the fact "that, up to now, the 'absolute' results of modern philosophical approaches to controversial political and juristic evaluations are almost negligible," "there is 10 need for defeatism." Come, rise all ye hopeful : the Absolute Is-ought is just around the corner. But don't hold your breath. 